\title{
ИСПОЛЬЗОВАНИЕ СЕЙСМОСТРАТИГРАФИЧЕСКОГО МЕТОДА ДЛЯ СОПОСТАВЛЕНИЯ ПЛАСТОВ НЕОКОМА РАЗЛИЧНЫХ ЛИТО-ФАЦИАЛЬНЫХ РАЙОНОВ ЗАПАДНОЙ СИБИРИ
}

Новосепова О.А., Аксенов Д.В., Белатиова И.В., Сокольникова А.А.

(ООО НППГМ «Геосейс»)

В докладе приводятся сведения из истории стратификации меловых отложений в Западной Сибири. Представлен вариант литологостратиграфического расчленения мелового разреза с детализацией неокомского интервала, по результатам комплексной интерпретации материалов региональных сейсморазведочных работ МОГТ и глубокого бурения в различнњх лито-фациальньх районах Западной Сибири.

Согласно региональной стратиграфической схеме 5-ого Межведомственного регионапьного стратитрафического совещания по мезозойским отложениям Западной Сибири (1991г.) принято районирование по типам разрезов неокомских отложений. Территория исследований охватывает Полуйско-Ямальский (Полуйский подрайон), ЕнисейХатантский (Малохетский подрайон), УренгойПурпейский (Уренгойский и Пурпейский подрайоны), Тазовский, Туруханский, Березовский, Фроловский, Тобопьско-Надымский, Сургутский, Вэнгапурский, Ларьякскнй, Нижневартовский и ЧулымоЕнисейский лито-фациальные районы.

Граница между фациальными районами не является строго закрепленной и связана с наличием переходных зон, достигающих десятки километров, в пределах которых присутствуют элементы как одного, так и другого соседних типов разрезов.

Практической основой расчленения, корреляция и индексации служжат эталонные разрезы по скважинам, принятые на основе разбивок А.Л. Наумова. При интерпретации разрезов скважин использовались литолого-геофизические маркирующие горизонты, которыми являются регионално следящиеся трансгрессивные глинистые пачки.

В пределах региона сформпрована уникальная сеть субширотных и субмеридиональных региональных профилей, по линиям которых была выполнена сейсмогеологическая корреляция.

В качестве инструмента объективного прослеживания одновозрастных или аналогичных по своему стратиграфическому положению стратонов исполюзовался сейсмостратиграфический метод, хорошо зарекомендовавший себя в условиях Западно-Сибирского осадочного бассейна. В результате выполненньг исследований прослежены отражающие горизонты Нпим, Нсарм, Нqеус, Нмох, Нур и Нсам, распространенные практически по всему региону и контролируюшие в разрезе нижнемеловых отложений ачимовские клиноформенные пачки и пласты (снизу вверх):

- Нсам - подошва самотлорской глинистой пачки, горизонт приурочен к кровле пласта БВ 8 и его стратиграфическими аналогами являются пласты БП $16,5 У_{20}, \mathrm{БT}_{9-10}, \mathrm{CД}_{8}$;

- Нур - подошва урьевской глинистой пачки, кровля комплекса приурочена к пласту БВ 6 , стратиграфические аналоги - БП $12, \mathrm{EУ}_{16}, \mathrm{ET}_{6}, \mathrm{CД}_{6}$ :

- Нмох - подошва моховой глинистой пачки, кровля пластов $\mathrm{EC}_{13-14}, \mathrm{~EB}_{3-4}$ и их стратиграфических аналогов - $\mathrm{E \Pi}_{10}, \mathrm{5Y}_{15}, \mathrm{ET}_{5}$;

- Нчеус - подошва чеускинской глинистой пачки (Сургутский и Пурпейско-Уренгойский типы разрезов), горизонт приурочен к кровле пласта $Б_{10}$, $Б_{7}, Б_{10}$, и его аналогов в соседних литофациальных районах $-\mathrm{AB}_{8}, \mathrm{ST}_{2-3}, \mathrm{CD}_{2}$;

- Нсарм - подошва сармановской глинистой пачки (юго-западная часть провинции),

кровля пласта $-\mathrm{БC}_{8}$, и ее аналог «шоколадная» глинистая пачка (северная территория) [ пласты $\mathrm{AB}_{7}, \mathrm{Б \Pi}_{2-3}, 5 \mathrm{~V}_{8}{ }^{\circ}, \mathrm{БT}_{0}, \mathrm{CД}_{1}$;

- Нпим - подошва пимской глинистой пачки, регионально прослеживаемая в центральной части Западной Сибири, кровля комплекса приуродена к пласту $\mathrm{BC}_{1}$ и его стратитрафическим аналогам в шельфовой части комплекса - $\mathrm{AB}_{4}, \mathrm{A \Pi}_{10}, \mathrm{AT}_{8-9}, 5 \mathrm{~V}_{3-}$ 4.

Детализация и уточнение стратиграфия отложений баррем-бериасского Западно-Сибирской нефтегазоносной провинции имеет важное практическое значение для прогнозирования новых перспективных ловупек и построения геологических моделей месторождений углеводородов.

Применение сейсмостратиграфического метода позволило установить взаимоотношения в разрезе пластов групп БС, БВ, БП, БТ, БП в различных лито-фациальных районах Западной Сибири. В результате проведенных исследований закартированны основные сейсмогеологические границы, контролирующие клиноформенные образования, изудение последних дает оценку перспектив их нефтегазоносности, обоснование направлений и выбора объектов геологоразведоңных работ. 